\title{
Pesantren Managerial Competence
}

\author{
Marwazi Marwazi* \\ Faculty of Education and Teacher Training \\ UIN Sulthan Thaha Saifuddin Jambi \\ Jambi, Indonesia \\ *marwaziabdhamid@gmail.com
}

\begin{abstract}
Modern education management theory needs additional tools to evaluate the performance of leaders managerial of pesantren or Islamic boarding school. The management of pesantren uses both modern theories and also uses management concepts based on religious beliefs such as sincerity and generosity, even in special ways so that modern educational management theory can run well and appease. The research objective is to study the management of pesantren based on the concept of management from religious views as a comparison to the modern educational management concepts. The research method is auto-ethnography and grounded theory, which are based on the experiences of the researcher in managing a pesantren in Jambi. This research found that the education management of pesantren could run based on the planning and modern management because it is supported by the management concept which is based on religious beliefs, such as prayer, dzikir, special wirid, mujahadah, and riyadhah batiniyah. The success and competence of pesantren leaders in managerial could be measured and seen in terms of infrastructure, the educational process, and the achievements.
\end{abstract}

Keywords: modern education management, pesantren education management

\section{INTRODUCTION}

Management of educational institutions, both modern and pesantren (Islamic boarding School), each strives to advance the institution, for the process and results, facilities and infrastructure, human resources and surrounding natural resources. Each of it wants the success of the institution, from the elements of its management, students, supporting infrastructure, and others.

Progress and success are determined by the managerial competence (expertise or skill) of the leader, and the parameters of progress and success are sometimes different between modern and pesantren; in general, the success of modern management-based educational institutions is measured by the grandeur of the building and its facilities and graduates who can achieve worldly success, both materially and in a position in the community or government. In pesantren it is sometimes the same, but pesantren graduates do not only want those because the student who comes back and then become a sincerely religious instructors (Mundziru alqaum) sincerely alive and lead the mosque is a big man for some pesantren's leaders.
In general, the managerial process that runs in nonpesantren educational institutions, runs from 07.00 am to $04.00 \mathrm{pm}$ for 5 working days from Monday to Friday, while in pesantren the process runs overnight and is commonly referred to as 24 hours, this is reasonable because its citizens (leader's families, some teachers, and students) live in one community, like a large family.

Modern educational institutions are more centralized, where the managerial process is determined by the education office or regional ministries, the authority of the institution is very limited by central policy. In contrast to pesantren, it is more independent and community-based (school based on management and community), there is even a statement in pesantren that rather "extreme", pesantren has no superiors, because the one above is only God and below it is the earth. From this institutional managerial, schools are rather limited, but in pesantren it is quite free, for it is curriculum and the process of managing facilities, students, and teachers and their families.

Therefor, when researchers want to know more about how the managerial process in pesantren, it is better to use the graunded recearch approach, not the scientific management approach, because the concept of "modern" management may not be able to see and accommodate all managerial activities of pesantren, in other words management "modern" does not enough to be used to conclude the managerial process in pesantren.

In this chapter, a study of modern management and pesantren management as a critical philosophical comparative study will be described, because there are some things in pesantren which are not enough to be understood only logically, but it must be understood spiritually.

\section{RESEARCH METHODS}

The method using in this research is qualitative and autoetnography study with data collecting through observations, interviews and discussion with pesantren teachers and students during live in author in a pesantren in Jambi. Author has experience for more or less twenty years involve in pesantren management. Analysis on data's through comparing empirical auto-ethnography data with theories on modern managerial competencies. 


\section{RESULTS AND DISCUSSION}

\section{A. Modern Managerial Competencies}

Some experts (fakkar) [1] of management explained that there are several stages of management, they are planning, decision making, organizing, leadership, and controlling; different from Henry Fayol, there are; planning, commanding, coordinating, and controlling; but the most famous is abbreviated as POAC (planning, organization, actuating, and controlling [2]. Those stages sometimes called by a management function, where some functions are an inseparable unity between one another, if there is one or even more abandoned, then the management process does not run well.

According to Ahmad Ibrahim Abu Sinn, the leader must have some competences that reflect the special characteristics (khashaish-caracteristic) of leadership. This competency is related to:

- Strategic competence is the leader insight to know the situation, condition, social environment, politics, culture, economy, law, security and so on. This competence is realized by a leader by managing human resources and other resources to achieve goals, make strategic plans and policies that must be implemented. Rasulullah SAW. has done in his history by trying to free the Muslims from the various tortures of the Quraysh infidels, when the torment became more and more, he ordered them to come out (migrate) from the City of Mecca.

- Interpersonal competence (communication) is the ability to find out the conditions of subordinates under his leadership. The leader must foster good relations, communicate and interact with subordinates and all elements of the organization so that unity of understanding can occur. The shape is like:

a) Demonstrate good role models for all its activities,

b) Have a good social interaction with subordinates, concentrate on their problems and act fairly.

c) Invite subordinates to consult and respect their opinions. Train subordinates to carry out their duties and mandates.

d) Have confidence in the abilities of subordinates and delegate some authority.

e) Supervise and audit the performance of subordinates in a mandate manner.

- Technical competence is the ability to adjust the work he is facing or the ability of certain equipment to facilitate the work [3].

Hogan \& Warrenfeltz, quoted by Maxwell Asumeng, divided the managerial competency domain model including:

- Business competence, namely skills related to technical knowledge for work, budget monitoring and job appraisal.
- Intrapersonal competence, namely skills related to selfcontrol and emotions, and self-evaluation.

- Interpersonal competence, namely skills related to initiative, building and maintaining relationships with others.

- Leadership competence, namely skills related to the ability to influence, motivate and encourage others to work to achieve the vision and mission [4]

Claudia Cristina Bitencourt states that there are 4 pillars of managerial competence, they are:

- Competence of organizational knowledge, namely knowledge and understanding of organizational policies and operational procedures.

- Competence to lead and manage human resources, the ability to overcome employee problems, occupational safety and health, teamwork in organizations.

- Competence in managing non-human resources, namely managerial ability related to the management of facilities and infrastructure, other non-human budget in the organization.

- Effective communication competence, which is the ability to interact between personnel in organizations [5].

Managerial competencies in an organization / company according to Wibowo are:

- Flexibility, that is the desire and ability of managers to change managerial structures and processes if needed.

- Implementation of change, that is the ability of leadership to communicate organizational needs for change to subordinates.

- Entrepreneurial innovation is the motivation to spearhead and excel by bringing up new products.

- Understanding human relations, namely the ability to understand and assess the input of others who are different.

- Empowering is managerial behavior for sharing information, participative collecting subordinate ideas, encouraging work development and delegating responsibility.

- Facilitating the team which is a group process skill needed to get different groups to work together.

- Ease of adjusting is the ability to adjust quickly [6].

Managerial competence for a leader according to Sedarmayanti are:

- Competence of decision-making quickly and accurately towards the problem.

- Competence to make a planning and management. 
- Competence of special school/madrasah service units for supporting learning activities and student activities in schools/madrasah.

- Network competence. The leader can work together and create a wider network.

- Competence of strategic oriented, the leader knows about strategic management, and strategic plans.

- Competence of leadership for a change. The leader has an innovative and creative spirit based on the situation and conditions [7].

Managerial competence is also reflected in the Regulation of the Minister of National Education of the Republic of Indonesia Number 19 of 2007 concerning Education Management Standards, which includes:

- Competence of program planning: vision, mission, goals and work plans of education units.

- Competence of work plan implementation: school guidelines, organizational structure, implementation of school activities, student fields, curriculum and learning fields, education and teaching staff, facilities and infrastructure, finance and financing, culture and school / madrasah environment, community participation and school / madrasah partnerships, and

- Competence of supervision and evaluation: supervision programs, self-evaluation, curriculum evaluation and development, evaluation of the utilization of educators and education personnel, and accreditation,

- Leadership and Management information system [8].

Managerial competence according to Permendiknas No. 13 of 2007 concerning Standards for School/Madrasah Principals including:

- Competence in arranging school/madrasah planning for various levels of planning.

- Competence in managing school/madrasah facilities and infrastructure in the context of optimum utilization.

- Competence in managing school-community relations in the context of seeking support for ideas, learning resources, and school / madrasah financing.

- Competence in managing students, especially in the context of new students admission, student placement, and capacity building of students.

- Competence in managing curriculum development and teaching activities according to the direction and objectives of national education.

- Competence in managing school finances according to the principles of accountable, transparent, and efficient management.

- Competence in managing school/madrasah administration for supporting school/madrasah activities.

- Competence to apply the principles of entrepreneurship in creating innovations that are useful for the development of schools/madrasah.

- Competence in creating a conducive culture and work climate for students learning.

- Competence in managing school/madrasah information systems for supporting program preparation and decision-making.

- Competence in utilizing information technology advancements to improve learning and school/madrasah management.

- Competence in managing production/service activities for supporting school funding sources and as a source of student learning.

- Competence of supervision towards the implementation of school/madrasah activities according to applicable supervision standards [9].

Managerial competence itself is planning and administrative competence, which is the competency that involves and decides what tasks needed to be done, determines how they can be done, allocates resources that allow them to be done, and then monitors the progress of work [10].

Based on a number of expert opinions regarding managerial competence, there are at least 14 managerial competencies, those are strategic/planning, interpersonal and intrapersonal, technical, organizational knowledge, task distribution/organizing, communication, entrepreneurship/ business, empowerment, teamwork, subordinate development, netting, leadership, management information systems and supervision. Indicators of managerial competence for a head/leader are as follows:

TABLE I. MANAGERIAL COMPETENCE INDICATOR [11]

\begin{tabular}{|l|l|l|}
\hline No & \multicolumn{1}{|c|}{ Indicator } & \multicolumn{1}{c|}{ Sub indicator } \\
\hline 1. & Planning & Arranging work programs \\
\hline 2. & Organizing & Division of tasks and work \\
\hline 3. & $\begin{array}{l}\text { Mobilization / } \\
\text { leadership }\end{array}$ & Leading and encouraging subordinates to work \\
\hline 4. & Supervision & $\begin{array}{l}\text { Monitoring the activities of subordinates and } \\
\text { make reports on monitoring activities }\end{array}$ \\
\hline
\end{tabular}

Based on the table above, it can be explained that managerial competence indicators include: a) planning for human resources and natural resources and organizational work programs (work plans, both short, medium, and long term), b) composing the parts or the organ (division of tasks and work), c) mobilizing the activities of the institution or organization, d) controlling which includes monitoring and evaluation, and making a report on the implementation of company activities. 


\section{B. Pesantren Managerial Competence}

Pesantren management is a sequence of traditions (sunnah) management of educational resources in pesantren based on al-Qur'an, al-hadith, and the practice of salaf ashshalih and ijtihad results of managers both based on thought and imitating modern management. This happened because of a principally and opened idea in pesantren, that is "keep a good old tradition and take a new better" [12].

Consciously, pesantren leaders carry out their managerial tasks in line with modern theories, though not all, and it does not always imitate modern managerial opinions and thoughts, but because they apply known or understood Islamic values, because Islam does not only contains any teachings about theology and pure worship (mahdhah), but also contains any managerial values, social, economic, politic, etc., as mentioned in an-Nahl / 16: 89: "... And We (Allah) sent down the Book (al- The Qur'an) to you (Muhammad SAW.) as clarification for all things and as guidance and mercy and good tidings for the Muslims [13].

What is included in the section of the paragraph above, which "as clarification for all things" is about the management system, competence. Generally, in Islamic teachings are found some management values relating to work plans, work motivation, ways of work, work together, leading, evaluating, controlling, and so on, even with special ways to be successful in the work, through from prayer, dhikr, wirid, mujahadah (pouring out all abilities), riyadhah batiniyah (training/mental exercise: wake up in 2/3 nights for worship), and so on to get taufiq (success in carrying out deeds) from Allah, His hidayah (instructions to carry out the deeds), and His maunah (help in running deeds) from Allah SWT.

In fact, in the period before Islam, management was already there and done well and produced, but the management's term did not exist till around 1886. If there were no good managerial processes, there would be no Cheops pyramid in Egypt, Borobudur temple, Prambanan temple, and other temples in Indonesia [14]. So it is very reasonable that there are good managerial activities in pesantren, because the leaders of pesantren are intelligent men who have the hidayah batiniyah (guidance and instruction in courage) from Allah, hidayah aqliyah (resourceful intelligence) and hidayah Islamiyah (guidance and perfect Islamic teachings) ), so if there is a big plan, the leader will fast in the day and do istikharah prayer in the night. In the pesantren, to decide a plan or program will be rather slow, but if it has been decided, it will be done immediately.

Based on the statement above, the theories or managerial systems contained in the modern management system are also practiced in pesantren's environment according to the conditions and competencies of the leaders. The theories or managerial systems are not only practiced according to the conditions and competencies of the leaders, but it is added with sincerity, exemplary behavior, simplicity, a sense of togetherness (ruh al-jamaah), complemented by certain wirid or riyadhah, after the fardu and other prayers, both in the daytime and midnight. Almost none of the leaders of the pesantren left those sunnah, because that is a part of the guidance of Islam, although there are some different opinions about it and different levels of faith and devotion.

Pondok Modern Gontor, in Ponorogo and its 19 branches, in its management, rationally and spiritually adheres to Panca Jangka (five futures plans), they are education and teaching, regeneration, buildings (infrastructure), khizanatullah (funding), and family prosperity. These five futures plans, are carried out properly and consistently by all sections, starting from the waqf organization, the leader, and other parts that assist the leader in managing pesantren. In that process, it is always supported with five spirits (Panca Jiwa), they are sincerity, simplicity, independence, Islamic brotherhood, and freedom. With this managerial pattern, Pondok Gontor has demonstrated its success that has been recognized domestic and abroad [15].

In the process of managing the institution, apart from the modern management actions as mentioned above, there are some pesantren leaders who prefer to do the fasting of Daud for many years (a day to eat and a day to fast), some do fasting of Nuh; who never eat lunch except two Eids and tasyriq days (11th, 12th, and 13th of Dzulhijjah). Some do 50 years of fasting, 10 years to pray for their children and 40 years to pray for the pesantren), some refrain from eating rice while leading pesantren, but only eat cassava. There are those who never sleep at night, except for very few, merely to put their trust in Allah. There are who never leave fardu prayer together, except for some reasons. There are those who read certain prayers or shalawat hundreds even thousands times, and so on [16].

All those are to increase the devout to Allah SWT, so with that devotion He will make for him a way out. (Q. At-Thalaq / 65: 2) [17], and whoever fears Allah- He will make for him of his matter ease (Q. At-Thalaq / 65: 4) [18]. So in pesantren it is common to manage certain budget assistance, which can exceed the predetermined target, even if the assistance is 100 million, for example, then the accountability report usually exceeds the funds, because the assisted also helps or adds. This is very different from the general phenomenons outside pesantren. Honesty in pesantren is so highly respected, because of the result of the devotion.

For this reason, it can be concluded from several statements above that pesantren managerial competence is a set of management skills possessed by its leader in order to achieve its vision and goals, which are complemented by certain religious sunnah practices in order to get taufiq, guidance, and maunah from Allah SWT. Indicators of managerial competence in pesantren are the capabilities of pesantren leaders in compiling work programs, dividing tasks, leading and encouraging subordinates to work, and supervising the work of employees according to existing goals; where the religious spiritual approach varies between a leader of pesantren with others.

Religious spiritual approaches that is different from one leader to another, is reasonable, because of the different perspectives on the practice of the sunnah, dzikir or special wirid (khash [19]), those are the level of religious inclination 


\section{REFERENCES}

(spiritual or rational approach), educational background, religious understanding, devotion, etc. Those type of approach is also different, from its practicing, its reading, its time, its volume, its method, and so on.

\section{CONCLUSION}

Managerial competence in pesantren is essentially permissible or rational and spiritual abilities possessed by its leader kyai or mudir or ustadz in managing pesantren, which is a set of management skills possessed by the leader in order to achieve his vision and goals, which are complemented by the practice of sunnah. In order to get taufiq, guidance, and maunah from Allah SWT. Indicators of managerial competency in pesantren are the skills of its leaders in preparing work plans, dividing tasks to staff and subordinates, leading and encouraging them to work, and supervising the work of employees according to the objectives.

Managerial process in pesantren is characterized by the sense of togetherness between kyai, teachers, and students in one place and one time, supported with a sense of sincerity (solely for and because of Allah SWT, Kyai teaches sincerely and students are taught sincerely), simplicity (according to the needs not the volition, independence (not dependent on other parties, independent), and freedom (not bound by dogma and tradition, but still in line with religion). In achieving a good management, plans are made to regulate work priority scale, distributed to the organs in the structure, carried out properly, correctly and responsibly, controlled by the highest one, especially the Khaliq, Allah SWT.

This study implify a deep research in the future especially on publishing pesantren management as an alternative for school management which was offered by occidental modern education management.
[1] Fakkar (Arabic language) in term it is called by shighah mubalaghah (emphasized form), means a person with a high level of skill or knowledge, then reserved to Indonesia language as pakar.

[2] H. Usman, Manajmen (Teori, Praktik, dan Riset Pendidikan), (Jakarta: PT Bumi Aksara, 2011), p.30.

[3] A.I.A. Sinn, Al Idârah fî̀ Al-Islâm, Terj. Dimyauddin Djuwaini (Jakarta: Raja Grafindo Persada, 2008), p. 134-149. 2008.

[4] M. Asumeng, "Managerial Competency Models: A Critical Review and Proposed Holistic-Domain Model", Macrothink Institut, Jornal of Management Research, Vol. 6, No. 4, 2014, p. 7-8.

[5] C.C. Bitencourt, Managerial Competence Management- The Organizational Learning Contribution. 2001. [Online] Available at: http://www2.warwick.ac.uk/ fac/soc/ wbs/conf/ olkc/archive/oklc5/papers/i-3_bitencourt.pdf

[6] Wibowo, Manajemen Kinerja, (Jakarta: Rajawali Pers, 2016), p. 281282.

[7] Sedarmayanti, Perencanaan dan Pengembangan Sumber Daya Manusia, (Bandung: Refika Aditama, 2017), p. 243.

[8] Unknown, Peraturan Menteri Pendidikan Nasional Republik Indonesia Nomor 19 Tahun 2007 Tentang Standar Pengelolaan Pendidikan, (Jakarta: Badan Standar Nasional Pendidikan, 2018), p. 5-39.

[9] Unknown, Permendiknas No. 13 Tahun 2007 tentang Standar Kepala Sekolah/Madrasah, (Jakarta: Depdiknas, 2018), p. 1-10.

[10] Slocum, John W., Jr., Susan E. Jackson and Don Hellriegel, Competency-Based Management (Mason USA: South-Western, Cengage Learning, 2008), p. 14-26.

[11] M. Abdullah, Manajamen Bisnis Syariah (Yogyakarta: Aswaja Pressindo, 2011), p. 76.

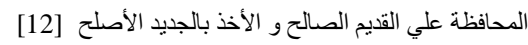

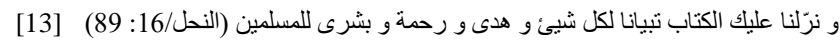

[14] H. Usman, op. cit., p.23

[15] See Wardun (Warta Dunia Pondok Modern Darussalam Gontor), Vol. 71, Sya'ban 1439 (Ponorogo: Darussalam Press, 2018).

[16] An interview with some people those are close to kyai and bunyai in Banten, Ploso Kediri, Lirboyo Kedri, Gontor Ponorogo, Jambi, and Jakarta.

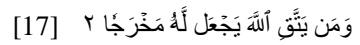

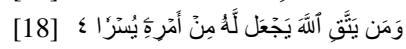

[19] Any readings as dzikir, prayers, and any certain practices did in some certain times, in general did after fardu prayer. Special wirid (khash) as done by Sufism is after sunnah prayer in $2 / 3$ nights. See Ensiklopedi Hukum Islam, jilid 6, (Jakarta: PT. Ichtiar Baru Van Hoeve, 2000), p.1951. 